ROCZNIKI TEOLOGICZNE

Volume 65, issue 8 - 2018

Englis h version

DOI: http://dx.doi.org/10.18290/rt.2018.65.8-2en

\author{
DOMINIK JURCZAK OP
}

\title{
“A PRECIOUS PEARL.” ON LITURGICAL DEVELOPMENT
}

\begin{abstract}
A b stract . Every liturgy grows. The liturgy of the Order of Preachers was no exception. In the $1200 \mathrm{~s}$, the friars faced the necessity to revise their customs, texts, and rituals. On the one hand, this situation shows how diverse the $13^{\text {th }}$-century Christianitas was, and on the other hand, it proved the presence of a desire for unity within the newly formed Order, a struggle to have all the members of the then-worldwide community pray according to the same form. The process leading to that "liturgical consensus" needed by the Preachers back in the 1200 s resembles the axioms of the liturgical renewal in the $20^{\text {th }}$ century. The article focuses on the history of the Dominican liturgical developments, highlighting the mindset of the 13th-century Friars Preachers facing changes in the area of prayer. In the context of debates surrounding the liturgy after Vatican II, the author provides a historical perspective in order to show similarities between both processes of liturgical renewal.
\end{abstract}

Keywords: history of the liturgy; development of the liturgy; liturgical reforms; Order of Preachers; Dominican rite.

At times we are convinced that there is a huge breach between $21^{\text {st }}$ century and $13^{\text {th }}$ century Christians. Indeed, there are many things that make us different, many dimensions have undergone transformation, not to mention the geopolitical situation, technological development, and anthropological or spiritual sensitivity. It seems, however, that in many aspects, we are not really that far apart from each other. Whether we like it or not, we grew out of a medieval Christianitas, meaning from a shared vision of the world carved by generations of Christians. Our problems, even if we perceive them as exceptional, are in fact not so great; moreover, they do not place us in a better or worse situation. In other words, it is not like as if

Fr. Dr. Dominik JuRczaK OP-PhD in sacra liturgia, Pontifical Liturgical Institute (at Sant'Anselmo) in Rome, director of the Dominican Liturgical Center in Krakow, member of the International Liturgical Commission of the Order of Preachers and the Commission for Liturgy and Pastoral Ministry of the Archdiocese of Krakow; correspondence address: Convent of Sts. Dominic amd Sixtus (the Angelicum), Largo Angelicum 1, 00-184 Roma, Italy; e-mail: d.jurczak @ liturgia.dominikanie.pl 
modern solutions are better or worse. Those who think so either show their ignorance, yield to pride, or in the worst possible case, fall into one and then the other. It turns out that the emerging Order of Preachers back then faced similar questions which today, seven centuries later, stand before the Church. We are not talking about dogmatic truths but about liturgical issues. Worth mentioning are similarities and differences, for example, to acquire deeper love and understanding for the modern liturgy based on the history of the liturgy of the Order of Preachers.

\section{PROBLEMS WITH THE $13^{\text {TH }}$ CENTURY LITURGY}

Let us begin with the simple observation that we do not know much about the liturgy of the thirteenth century, and so we remain de facto in the sphere of hypotheses and suppositions. Whatever they may be, it is certain that the entire thirteenth century was a time of many transformations, affecting the Church and its liturgy. For example, it was a time of the development of universities, the rise and founding of scholasticism, a new way of describing reality related to Aristotle's thought, heterodox movements in Europe, and the like. In liturgical matters it is enough to follow the views towards concelebration to see how differently these matters were formulated at the beginning and at the end of the thirteenth century. ${ }^{1}$ Nor should we presume that the liturgy in Rome was one and homogeneous. Different characteristics were exhibited by rites which were celebrated by the Pope and his curia, there were other rites in the Lateran Basilica itself or at the Vatican, and still others ones in the remaining Roman churches. ${ }^{2}$ In this broad and multifaceted context, apart from Rome itself which was no less heterogeneous, it is fitting to include the liturgy of the Order of Preachers.

\section{SPECIFICITY OF THE LIFE AND PRAYERS OF THE FIRST GENERATIONS OF FRIARS PREACHERS}

In the first place, before we take off and draw far-fetched conclusions, let us clarify the picture we have sketched. Indeed, it is not insignificant that the

\footnotetext{
${ }^{1}$ Cf. Dominik JuRCZAK, "Il concetto di concelebrazione nel XIII secolo. Letturaliturgica di papa Innocenzo III e di Tommasod'Aquino," Ecclesia Orans no. 32 (2015): 387-429.

${ }^{2}$ Cf. Cassian Folsom, "I libri liturgici romani," in Introduzione alla liturgia, ed. Anscar J. Chupungco, vol. 1 (Casale Monferrato: Piemme, 1999), 287-288.
} 
first generation of Preachers did not have a clear "liturgical point of reference," meaning that they did not have a model that they could easily refer to and base themselves on. At St. Roman's Church in Toulouse in the summer of 1216 , the Preachers began their work, ${ }^{3}$ yet it would have been difficult to see it as the "Dominican headquarters," something similar to Cluny, Hirsau, Gorze, Prémontré, Cîteaux or the Abbey of Saint-Victor near Paris, even if the later mentioned had a lot in common with them, such as following the Rule of St. Augustine. The map of the nascent Order really has no such place like Assisi, from where the Friars Minor began to radiate the Franciscan form of life, using the Roman style of prayer. ${ }^{4}$

In comparison with them, the first generation of Preachers was much more "expansive," meaning that from the first days, their mission went beyond one single region. All this, at least theoretically, should have meant greater complications for the Order. Meanwhile, the Order was rapidly growing: already at the second general chapter in 1221, five years after the founding of the Order, eight provinces existed, and the presence of friars in Hungary, Germany (Teutonia) and England was mentioned. ${ }^{5}$ Thus, either the hypothesis of the thirteenth century liturgical differences is exaggerated (or simply untrue), or the Preachers found such solutions that allowed them to base these "liturgical centers" on something other than the liturgy of any one specific place, like Rome, Paris or Bologna, something important for the first generation.

To find an answer to this, let us try to characterize the way the Preachers prayed. We begin with the simple observation that they arose from the prolonged arrangements of Lateran Council IV. Canon 10 perfectly reflects the context in which the new Order is being formed, and it was not to be an escape from the world or a formation focused on self-glorification, carried out in a perfect way in a strictly defined place, but a response to the Church's specific needs:

\footnotetext{
${ }^{3}$ Cf. JoRdAn z SAKSONII, Ksiązeczka o poczq̨tkach Zakonu Kaznodziejów, transl. Mirosław Wylęgała (Warsaw: Oficyna Wydawniczo-Poligraficzna „Adam,” 2008), 41, no. 44.

${ }^{4}$ Cf. Joseph P. van DiJK, "The Authentic Missal of the Papal Chapel," Scriptorium no. 14 (1960): 260.

${ }^{5}$ Cf. William A. Hinnebusch, The Dominicans. A Short History (New York: Alba House, 1975), 19; Cf. Acta Capitulorum Generalium Ordinis Praedicatorum, vol. 1: Ab anno 1220 usque ad annum 1303 (= ActCG), ed. Franz Andreas Frühwirth, Benedictus Maria Reichert (Romae: Ex typographia polyglotta S.C. de propaganda fide, 1898), 2, v. 5-10.
} 
It often happens that bishops, due to their numerous obligations, ill health, enemy invasions or for other reasons, not to mention lack of knowledge, because in their case it is always blameworthy and would not be tolerated in the future, are not able to cope with the ministry of proclaiming the Word of God to the people, especially in large and extensive dioceses. Our general constitution dictates that bishops choose suitable men able to fulfill the service of holy teaching, those who are strong in word and deed, who would be eager to visit them since bishops themselves cannot go to the people entrusted to them, building them up by word and example. [...] Therefore, we recommend that in both cathedral and monastic churches, suitable men be appointed to be a bishop's coadjutors and co-directors, not only in the ministry of preaching, but also in listening to confessions, imposing penance, and in other matters for the salvation of souls $[\ldots] .{ }^{6}$

The ideal Preacher seems to fit perfectly into the portrait of these men (viri idonei), whose task is to be coadjutors and cooperatives of bishops (coadiutores et cooperatores), capable of the holy service of teaching (ad sanctae praedicationis officium), strong in deed and word (potentes in opere et sermone), and strengthening others by the word and example (verbo et exemplo aedificent). Their "location" remains an open question. Gathered together in the autumn of 1215, they mentioned cathedral and monastic churches. It seems that this could have been one of the reasons why the Preachers, whose Order was born a few months later, were so willing to set up new communities in big cities, at universities, and close to the bishop. In addition to all this, we cannot forget to mention that Dominic Guzmán $(\dagger 1221)$, having brought together the Dominican Friars, had already experienced the life of a Canon. With such a vision, the note that Jacob of Vitry $(\dagger 1240)$ left behind in his Historia Occidentalis, a work completed a few years after Dominic's death, seems very meaningful:

The community of canons regular, pleasing to God and to the people, lives outside the city, but not far from Bologna. They fight under the banner of the Eternal God, serve under the authority of one superior, in sacrifice and humility, with a fervent spirit and a well-prepared mind. [...] Three times a week they agree to eat meat if it is offered to them; they eat together in the refectory and rest in a common dormitory. They are also sing the canonical hours in the church, according to the Rule of St. Augustine, joyfully trusting in the Lord, offering to God a sacrifice of prayer and giving to the Most High what they have promised him. [...] Gathered together under the Lord's inspiration, they listen to lectures on the Holy Bible daily, which one of them preaches. That which they so diligently listened to they give to the faithful on feast days through their preaching ministry, having received

\footnotetext{
${ }^{6}$ Dokumenty Soborów Powszechnych. Tekst grecki, taciński, polski, vol. II:(869-1312) Konstantynopol IV, Lateran I, Lateran II, Lateran III, Lateran IV, Lyon I, Lyon II, Vienne, ed. Arkadiusz Baron, Henryk Pietras (Kraków: Wydawnictwo WAM-Księża Jezuici, 2007), 244-247, can. 10.
} 
this right from the Pope and in accord with the regulations of the Holy Roman Church. They enhance the canonical rule and sacred monastic observances through the gift of preaching the word and teaching, thus uniting into one the preaching order and the canonical order. ${ }^{7}$

If we want to guess what the prayer of the first Preachers could have looked like, then we should definitely look for inspiration in the canonical liturgy. Most certainly, the new Order was not supposed to be a carbon copy of canonical chapters, maybe even unified with the Christianitas of that time. What they wanted to create was a formation of "new canons" who, together with common prayer, were always focused on the bishop (not necessarily physically but theologically), especially the bishop of Rome, from whom they directly received their mission. They would respond to shortcomings in "the ministry of proclaiming to the people the word of God, especially in large and extensive dioceses." "If Jacob of Vitry's description is considered normative, a balance between the prayer life and the mission of the first Preachers is worth emphasizing: one does not exist without the other, and what is more, they mutually condition each other. ${ }^{9}$

In other words, even if the Order was to carry out the ministry of preaching, and the Friars themselves define their theological assignment as Preachers, at the very beginning of their mission, there is a common liturgy and preparation for their ministry. Worth noting is the order of events that Jacob of Vitry describes according to the lifestyle of the "new canons." First, he mentions the canonical hours, and we should add, the sung "offering prayer," done several times a day, then a daily lecture based on Sacred Scripture, and perhaps on occasion the pretiosa. It is only in the next point that he mentions the ministry of preaching addressed to others: it is not done every day, but only on feast days. Their liturgy, therefore, even if we do not know too much about it, was the foundation for preaching, and moreover, by

\footnotetext{
${ }^{7}$ JAKUB Z VITRY, "Historia Occidentalis, cap. 27 (De noua religione et predicatione bononiensium canonicorum)," in The Historia Occidentalis of Jacques de Vitry. A Critical Edition, ed. John Frederick Hinnebusch (Fribourg: The University Press, 1972). Guy Bedouelle, Dominik czyli taska Stowa, transl. Janina Fenrychowa (Poznań: W drodze, 2011), 313-314.

${ }^{8}$ Dokumenty Soborów Powszechnych, vol. II, 244-247, can. 10.

${ }^{9}$ Cf. Dominik JURCZAK, "Ut studium non impediatur. La relazione tra la preghiera e la „missione” nella prima generazione dei Frati Predicatori," in 'Carmina laudis'. Risposta nel tempo all' eterno. La liturgia delle Ore tra storia, teologia e celebrazione. Atti del X Congresso Internazionale di Liturgia Roma, Pontifico Istituto Liturgico, 6-8 maggio 2015, ed. Eduardo Lopez Tello García, Stefano Parenti, Marcus Tymister (Canterano: Arcaneeditrice, 2016), 493-500.
} 
embracing and fulfilling their bishops' assignments, this gave them the charism of being not only praedicantes, but also praedicatores. ${ }^{10}$

It can be assumed that what joined the first generation of Preachers and kept their project unified was a clear mission and the Rule of St. Augustine, which described the life of the Friars. Both appealed to the person of Dominic as well as his earlier experiences as a canon. It is not difficult to predict that problems would follow just after the founder's death. Jordan of Saxony ( $† 1237)$, Dominic's successor, in the context of preparations for the canonization of his predecessor (1233-1234) writes in the "heritage of the Preachers" that "some harsh habits regarding food, fasting, bedding and woolen clothes" $" 11$ will remain in accord with the descriptions of Jacob of Vitry. However, these customs, in order to have binding force, had to be found in the Preachers' legislation. Indeed, their first constitutions codify some of them, ${ }^{12}$ remaining in direct relation to the records of the Premonstratensians, ${ }^{13}$ or the "white canons," giving further proof of their closeness to this way of life. But did the artiores consuetudines that Jordan wrote about really suffice to keep the Order in unity, especially assuming the lack of their own Prémontré?

\section{DISABLING VARIETY AND THE FIRST STRUGGLES FOR UNITY IN PRAYER}

It is hard not to notice with the spread of the Order and the natural tendency to clarify customs and legislation, differences between the Friars

\footnotetext{
${ }^{10}$ Cf. Vladimir J. Koudelka, "Notes sur le Cartulaire se S. Dominique,” Archivum Fratrum Praedicatorum no. 28 (1958): 95-100.

${ }^{11}$ Jordan z SAKSOnII, "Libellus de Principiis Ordinis Praedicatorum," in Monumenta Historica Sancti Patris Nostri Dominici, ed. Heribert Christian Scheeben, vol. II (Romae: Institutum Historicum Fratrum Praedicatorum, 1935).Transl. after: JoRDAN Z SAKSONII, Książeczka o początkach Zakonu Kaznodziejów, 40, no. 42.

${ }^{12} \mathrm{Cf}$. Antoninus Hendrik Thomas, De oudste constituties van de Dominicanen. Voorgeschiedenis, tekst, bronnen, ontstaan en ontwikkeling (1215-1237) (Leuven: Bureel van de R.H.E., 1965).

${ }^{13}$ Cf. Simon Tugwell, "Introduction," in Humberti de Romanis Legendae sancti Dominici. Necnon materia praedicabilis pro festis sancti Dominici et testimonia minora de eodem, adiectis miraculis rotomagensibus sancti Dominici et Gregorii IX bulla canonizationis eiusdem ed. Simon Tugwell (Romae: Institutum Historicum Fratrum Praedicatorum, 2008), 1. A few documents are worth comparing (T1a, T1b, T2 i T3), which the author mentions in the appendix: Varia historiam lectionarii illustrantia (= VariTextus), in: Humberti de Romanis Legendae sancti Dominici, 579-580.
} 
also appeared, threatening to weaken the mission due to internal struggles. Whatever had the right to function in the Preachers' in statu nascendi in the long term demanded a more concrete response. The first dispute, indirectly referring to the liturgy, concerned the interrelation of Sacred Scriptures, and it was provoked by the Friars themselves, more precisely, by the decision of the General Chapter of Bologna in 1233:

\footnotetext{
Volumus et mandamus ut libri fratrum decedencium et maxime biblie extra nec infra ordinem vendantur sed pocius fratribus proficientinus concedantur. ${ }^{14}$

Volumus ut novicii qui tantam pecunaim habent ut solutis vestibus possint de illa emere bibliam et breviarium quod ex ea de residuo emant. ${ }^{15}$
}

It took only three years for the extraordinary General Chapter to deal with the consequences of the undertaken solution. We can presume that the decision of 1233 was motivated by the issue of poverty, but it also had consequences on the liturgy: on the one hand, it did not reduce the various types of breviaries in use, and on the other hand, the differences between biblical texts and their interpretations increased. It is hard to otherwise understand the strong statements from 1236 :

\footnotetext{
Nullus fratrum nostrorum legat in prophetis et in psalmis alium sensum litteralem nisi quem sancti approbant et confirmant. ${ }^{16}$

Volumus et mandamus ut secundum correctionem quam faciunt fratres quibus hic iniungitur in provincia [Francie] biblie alie ordinis corrigantur et punctentur. ${ }^{17}$
}

The development of events proving our suspicion of differences in the Christianitas at that time seems justified, at least regarding the texts. However, did the solution undertaken in 1236, meaning the correction of the text and its punctuation, solve these problems? It seems that to some extent it turned out to be effective, since in 1240 the General Chapter presented an analogous idea to what was done seven years earlier, namely the possibility of taking along books (including the Bible and the breviary) when it was necessary to move about between provinces. ${ }^{18}$ This solution was in accord with the regulations of the Preachers: the requirement was to be approved by

\footnotetext{
${ }^{14}$ ActCG, p. 4, v. 5-7.

${ }^{15}$ ActCG, p. 4, v. 12-14.

${ }^{16}$ ActCG, p. 6, v. 12-13.

${ }^{17}$ ActCG, p. 9, v. 13-15.

${ }^{18}$ Cf. ActCG, p. 14, v. 20-21.
} 
three successive chapters and was then approved by the General Chapter in $1242 .{ }^{19}$

General Chapters naturally undertake more decisions regarding the liturgy in the first years of the Order's existence, but most of them refer to "minor issues," such as body posture in the choir during the recitation of the shortest psalm, ${ }^{20}$ the use of a cape while reciting the office, ${ }^{21}$ instructions about paintings or stained glass windows, ${ }^{22}$ or the requirement to recite the "Our Father" five hundred times a day by the fratres conversi. ${ }^{23}$ All of them talk about the sensitivity of medieval man, different than the current situation. In other words, what may seem trivial to us was for the first generation of preachers a significant matter, interfering and changing their way of life so much that these things could only be solved by general chapters.

THE DECISION TO MAKE A REVISION

\section{AND THE FIRST "COMMISSION OF FOUR FRIARS”}

In the history of forming the Dominican liturgy, the year 1244 is an important ceasura. Of course, we must always keep in mind that the medieval mentality is different from ours. It turns out that the confusion over the lack of liturgical unity reached such a level that the General Chapter decided to organize the next meeting the following year in Cologne. Representatives of each of the provinces took with them liturgical books to make corrections in them:

\footnotetext{
Volumus et mandamus ut diffinitores proximo sequentis capituli generalis, pro concordando officio, portent secum ad dictum capitulum omnes rubricas et notulas breviarii nocturni et diurni, et gradualis et missalis. ${ }^{24}$
}

Where did they get this idea from? It was probably inspired by the efficiency of the decision in 1236. Perhaps, however, a solution proposed by the Roman Province played a part in this, which was to gather at the

\footnotetext{
${ }^{19}$ Cf. ActCG, p. 22, v. 8-10.

${ }^{20}$ ActCG, p. 8, v. 35-36.

${ }^{21}$ Cf. ActCG, p. 20, v. 5-3; Cf. ActCG, p. 22, v. 19-20; Cf. ActCG, p. 26, v. 5-7.

${ }^{22}$ ActCG, p. 11, v. 35-36; Cf. ActCG, p. 15, v. 9-12.

${ }^{23}$ Cf. ActCG, p. 13, v. 28; Cf. ActCG, p. 18, v. 31.

${ }^{24}$ ActCG, p. 29, v. 29-32; Vari Textus, p. 581, T6.
} 
Provincial Chapter "sub Fr Umberto tunc priore prouinciali" ${ }^{25}$ most likely even before 1244:

\begin{abstract}
Iniungimus fr. Petro lectori, et suppriori Romano, in remissionem omnium peccatorum, ut ipsi omnes epistolas et evangelia, kalendarium, regulam, constitutiones, capitula, orationes et collectas [colligant] et postmodum diligenter corrigant et versiculent et punctent secundum puncta debita et circumflexiones in libris conventus Romani; secundum quorum exemplum per totam provinciam libri similes corrigantur, versiculentur et punctentur. ${ }^{26}$

Quilibet frater, preter predicatores, qui scribere de littera competenter legibili, scribant unum libellum de officio sepulture, et priores ministrent pergamenum; qui libelli reponantur in sacristia. ${ }^{27}$

Fr. Ambrosio et fr. Umberto de Panzano committimus ut de consilio provincie, sive divisim sive insimul, faciant unum libellum qui dicatur lectionarium, tam de tempore quam de festis; qui, postquam fuerit diligenter correptus, versiculatus, punctatus, accipiatur ab aliis conventibus et scribatur. ${ }^{28}$
\end{abstract}

Whatever the case may be, it is hard not to see the correlation between the decisions of the Chapter of the Roman Province and the General Chapter of 1245. The latter decided to create a commission of four friars who would review and correct the office. The work was to start on November 1, and after their completion, the proposal had yet to be submitted to the Dominican legislative procedure (the approval of three ordinary chapters):

Committimus quatuor fratribus Francie, Anglie, Lombardie, Theotonie, quod stantes in domo Andegavensi officium nocturnum et diurnum in littera quam in cantu et rubricis corrigant et concordent, ac defectus suppleant, cum quanto possint dispendio minori, et quilibet de predictorum quatuor afferat tam nocturnum quam diurnum officium secum de provincia sua, et hec provinciales procurent, et sint in festo Remigii; et si qui non venerint, alii nichilominus procedant. ${ }^{29}$

We do not know why only four friars were in the commission, why only four provinces were invited, and why it was these four and not others?

\footnotetext{
${ }^{25}$ Monumenta et antiquitates veteris disciplinae Ordinis Praedicatorum ab anno 1216 ad 1348 praesertim in Romana provincia praefectorum que qui eandem rexeru nt biographica chronotaxis ex synchronis documentis, ineditis codicibus, aequalibus que auctoribus collectae, illustratae, acdigestae, ed. Pius-Thomas Masetti, vol. II (Romae: Typographia Rev. Cam. Apostolicae, 1864), 267.

${ }^{26}$ Acta Capitulorum Provincialium Provinciae Romanae (1243-1344), ed. Thomas Käppeli, Antoine Dondaine (Roma: Istituto storico domenicano di p. Sabina, 1941), p. 3, v. 3-9.

${ }^{27}$ Ibidem, v. 25-27.

${ }^{28}$ Ibidem, p. 4, v.10-14; Vari Textus, p. 581, T5.

${ }^{29}$ ActCG, p. 33, v. 3-9; Vari Textus, p. 581-582, T7.
} 
Maybe the biggest differences (in statements) existed between the mentioned provinces? Maybe it was because they were the most resilient? ${ }^{30}$ Yet it is surprising that a representative of the Roman Province was not present in the commission. What is more, we do not know the criteria according to which they wanted to revise the office. From this point of view, it seems that the whole process was accompanied by arbitrary decisions under the pressure of time, and they needed a quick solution to the problem. Whatever the case, the work began, and they proposed immediate changes, although things went slower than expected. As should be expected, not everyone was satisfied with the course of matters. This can be seen in the Acts of the General Chapter of 1246:

[Inchoamus] tota ordinacio ecclesiastici officii facta a quatuor fratribus .IIIIor. provinciarum, vel facienda usque ad annum, communiter per totum Ordinem observetur, et si in aliquo discordaverint, sentencia Magistri teneatur. ${ }^{31}$

The General Chapter of 1248 was the third in a row and ultimately confirmed the introduced changes. The problem, at least theoretically, was solved, which practically meant that wherever this had not yet been done, these corrections should be introduced. Traces of this can be seen in acts of the General Chapter of the Province of Provence:

\footnotetext{
Volumus ut prior lemouicensis duos fratres mittat ad aliquem conuentum Francie iuxta litteras prioris provincialis Francie ad habendam correctionem nouam breuiarii. $^{32}$
}

\section{"A CORRECTED CORRECTION" MEANING THE SECOND MEETING OF THE "COMMISSION OF FOUR FRIARS”}

In the history of the reception of the revised office, it seemed that matters were ultimately resolved and closed, but we can find an interesting note in the acts of the General Chapter of 1250 :

Cum multorum fratrum de diversis provinciis super discordia multiplici divini officii per .iiii. fratres ordinati querelas recipimus tempore capituli generalis,

\footnotetext{
${ }^{30}$ Cf. ActCG, p. 38, v. 22-27.

${ }^{31}$ ActCG, p. 35, v. 33-34; ActCG, p. 36, v.1-2; Vari Textus, p. 582, T9.

${ }^{32}$ Acta Capitulorum Provincialium Ordinis Fratrum Praedicatorum. Première province de Provence, Province Romaine, Province d'Espagne. 1239-1302, ed. Célestin Douais (Toulouse: Imprimerie et Librairie É. Privat, 1894), 34; Vari Textus, p. 584, T16.
} 
visum est magistro et deffinitoribus, ut ad sedendas querelas, predicti fratres in Methim veniant in festo omnium sanctorum ad correctionem dicti officii faciendam, et in unum volumen redigendam; quapropter mandamus et in remissionem peccatorum iniungimus quatinus ad predicta perficienda dicti fratres statuo tempore ad locum veniat memoratum. Interim autem a rescribendis libris vel corrigendis secundum predictam correctionem eorundem abstineant universi. ${ }^{33}$

First of all, it surprises us with a kind of "silent opposition" to the imposed changes. The explicite mention about the unrest and dissatisfaction of many friars means that these corrections had to be seen as controversial, and certainly difficult to approve of. It is worth noting that the introduction of changes began almost five years earlier. Unfortunately, we do not know what caused the greatest inconvenience, whether it was the text, the rubrics or the way of singing, etc. Second, a "reform of the reform" was ordered, meaning the same commission was asked to gather in Metz (France) in the autumn of 1250 and once again revise its previous work.

We do not know whether the "corrected correction" underwent consultations to quiet the dissatisfaction; we do know, however, that the next General Chapter in 1251 ordered even easier access to the corrected versions:

Officium diurnum et nocturnum secundum ultimam correpcionem ab omnibus recipiatur; et unum exemplar Parisius, aliud Bononie reponatur, et secundum eorum formam omnes libri ordinis scribantur vel corrigantur. ${ }^{34}$

Perhaps the problem of complaints was simply the lack of access to the correct version. It might be that the Chapter wanted to strongly speak on behalf of the "corrected correction." Most certainly, to calm emotions, the death of the General of the Order, John of Wildeshausen, in the autumn of 1252 did not help because, according to the regulations of the Preachers, the Chapter could not take place the following year. It was not until 1254 that the friars would gather in Buda and choose Humbert of Romans ( $\dagger 1277)$.

\section{REVISIONS BY HUMBERT OF ROMANS}

It seems that the choice of this provincial from the French Province was not accidental. It was not so much about "appreciating" one of the provinces,

\footnotetext{
${ }^{33}$ ActCG, p. 53, v. 31-35; ActCG, p. 54, v.1-5; Vari Textus, p. 585, T19.

${ }^{34}$ ActCG, p. 60, v. 4-7; Vari Textus, p. 586, T20.
} 
one in which general chapters are held, since this is not medieval thinking. The French Province was chosen because Paris was a university city with its own studium generale, one of the places where there was supposed to be a model code with the right version of the liturgy. The representative of the French Province was one of the four friars working to solve the problem. Maybe Humbert himself did this? The "reform of the reform" of 1250 took place in Metz, which territorially belonged to the French Province. Last but not least, everything points to the fact that Humbert, before becoming the Provincial in France, was the Provincial of the Roman Province, ${ }^{35}$ where the battle for the coherence and uniformity of the Preachers' liturgy began.

The Chapter which chose Humbert decided to act in two ways. On the one hand, they advised the new general to continue this work, and on the other hand, he gave all the friars the opportunity to comment, therefore, not only those who came to the Chapter:

Committimus magistro ordinis totam ordinationem ecclesiastici officii tam diurni quam nocturni et eorum que ad hoc pertinet et correctionem librorum ecclesiaticorum et quod corrigat litteram regule. ${ }^{36}$

Fratres quibus videtur aliquid corrigendum circa officium scribant magistro ordinis ad sequens capitulum generale. ${ }^{37}$

Regarding these objections from the friars, it seems that they were not only about the textual but also the ritual context. For example, one of the problems discussed between 1250 and 1252 was the osculum pacis rite, with the question of whether and to whom it would be offered during Mass. ${ }^{38}$ Another matter was including into the Preachers' liturgy the first Dominican martyr, Peter of Verona, canonized in $1254,{ }^{39}$ with the highest possible degree of celebration (totum duplex). This, however, meant another intervention in the liturgical books.

\footnotetext{
${ }^{35}$ Cf. footnote 25 .

${ }^{36}$ ActCG, p. 68, v. 28-31; Vari Textus, p. 586, T22.

${ }^{37}$ ActCG, p. 71, v. 20-21; Vari Textus, p. 587, T23.

${ }^{38}$ ActCG, p. 52, v. 25-29; ActCG, p. 56, v. 26-28; ActCG, p. 60, v. 18-20.

${ }^{39}$ Cf. InNOCENTY IV, "Magna magnalia (8 VIII 1254)," in Bullarium Ordinis Fratrum Praedicatorum. Sub auspiciis SS. D.N.D. Benedicti XIII, pontificis maximi, ejusdem Ordinis, ed. Thomás Ripoll; Antonin Brémond, vol. I (Romae: Ex Typographia Hieronymi Mainardi, 17291740), 252.
} 


\section{CRITERIA FOR THE INTRODUCED CHANGES. BETWEEN THE $13^{\text {TH }}$ AND $20^{\text {TH }}$ CENTURIES}

Taking into consideration that there could have been more similar matters, or at least more than the acts of the Chapter provide us with, it is worth asking about the criteria used to respond to this. How did they search for solutions? It seems that fidelity to one tradition would be too romantic, especially since there were many customs. Could the decisions made even by the General Chapters bear the marks of arbitrariness? Does a committee of four friars make it look like they simply made corrections "at the writing table"? These are just some of the arguments made by those who deny the assumptions of the twentieth-century liturgical reform, stressing that it has no precedent. At the same time, it seems that the Preachers formed their liturgy, over time called the Dominican rite, so that they would also better respond to internal problems and needs, both their own and the Church's. If we look at the preamble to the Constitution Sacrosanctum Concilium (CL 1) from this perspective, it turns out that the Preachers had similar assumptions seven centuries earlier:

\footnotetext{
This sacred Council has several aims in view: it desires to impart an ever increasing vigor to the Christian life of the faithful; to adapt more suitably to the needs of our own times those institutions which are subject to change; to foster whatever can promote union among all who believe in Christ; to strengthen whatever can help to call the whole of mankind into the household of the Church. The Council therefore sees particularly cogent reasons for undertaking the reform and promotion of the liturgy.
}

I am not sure if today this means the necessity of "correcting the reform," and I would be far from drawing quick, practical conclusions, yet the similarity is thought-provoking. Throughout history, especially in the history of the liturgy, we cannot go back in time, nevertheless, it takes wisdom not to pry through an already open door. What the Friars Preachers sought in the thirteenth century, alongside specific solutions, undoubtedly included unity and unanimity in prayer.

In order to bring the history of the liturgical formation of the Preachers to the end, the Order elected Humbert of Romans as General in 1254, and he assumes the responsibility of completing the work on the liturgy. Yet the General Chapter of Buda begins the Dominican legislative process to 
approve of "totum officium tam diurnum quam nocturnum $[. .$.$] secundum$ ordinacionem et exemplar venerabilis patris Humberti Magistri Ordini," ${ }^{40}$ which was finally completed in $1256 .{ }^{41}$ Humbert sends a letter to all the friars from this General Chapter concluded in Paris:

\begin{abstract}
Adhuc noveritis quod diversitas officii ecclesiastici, circa quod unificandum multa jam capitula sollicitudinem non modicam habuerunt, per Dei gratiam, ad unitatem, incertis exulantibus, est reducta. Rogo autem ut detis operam ad correctionem illius secundum illa, ut uniformitas officii diu desiderata in Ordine inveniatur ubique. Sciatis etiam quod impossibile fuit in ipsius ordinatione satisfacere voluntatibus singulorum; propter quod quilibet vestrum ferre debet patienter, si fortassis occurrerit ei aliquid in ipso Officio suae sententiae minus gratum. ${ }^{42}$
\end{abstract}

One can risk stating that from this moment on the Dominican liturgy for the next seven centuries, receives a unified form. The final act, ending the liturgical disputes, is the bulla Consurgit in nobis by Clement IV of 1267, which approves of the books of the Order. ${ }^{43}$

\title{
THE RIGHT PERSPECTIVE IN FORMING THE LITURGY
}

Finally, let us return to the doubts expressed at the beginning of our journey. First of all, is the hypothesis about liturgical differences in the $13^{\text {th }}$ century correct? Most certainly it is, and this is confirmed in the history of the emerging Order of Preachers, but the liturgy of the thirteenth century cannot be considered in the categories of a homogeneous liturgy. In other words, there was a specific kind of diversity. What is more, what seems to us to be an insignificant detail today was by no means so for the people of the Middle Ages. We are speaking about the textual layer, gestures and ceremonies. The mentality of the thirteenth century was also visible, and perhaps primarily, in the liturgy, and it was oriented so as not to lose this

\footnotetext{
${ }^{40}$ ActCG, p. 68, v. 32-35; Vari Textus, p. 586, T22.

${ }^{41}$ ActCG, p. 78, v. 12-15; Vari Textus, p. 587, T25a.

${ }^{42}$ Humbert Z Romans, "Epistolae Encyclicae, list 5," in B. Humberti de Romanis quinti Praedicatorum Magistri Generalis opera de vita regulari, ed. Joachim Joseph Berthier, vol. II (Torino: Marietti, 1956), 503; Cf. Vari Textus, p. 588, T28.

${ }^{43}$ Cf. KLemens IV, "Consurgit in nobis (7 VII 1267)," in Bullarium Ordinis Fratrum Praedicatorum, 486-487.
} 
"precious pearl" (Cf. Mt 13:44-46), but it took into account the situation and challenges of the moment to hand it on to future generations.

Therefore, especially with reference to the Order itself, there is a need for unification, meaning one way to do things binding all its members. Contemporary mentality, meanwhile, emphasizes diversity, in which a decisive emphasis is placed on "experiencing" a religious experiment. Liturgy therefore becomes less of a "precious pearl" and more of a means of expression. Unfortunately, this disintegration seems to be deepening. If, therefore, we want to express doubts about the post-Conciliar renewal of the $20^{\text {th }}$ century, then, according to my conviction, these first refer to the mentality along with all its consequences, and only then to the methodology of the work itself.

Second, if the Preachers did not build their "liturgical center" on a geographical reference point, what was the foundation of their liturgy? It seems that along with all of the liturgical corrections of the Order being formed, supported by other theological and non-theological factors, the Preachers supported the formation process of Christianitas. Such a strong desire for unity and a unified way of prayer was not without significance. Moreover, it had an impact on the liturgy of the Church in subsequent centuries. What from the liturgical point of view seems to be characteristic of the Preachers is in fact, despite diversity, that they not only united a uniform way of life (ordo), but also a certain vision of theology, and thus also prayers, all consistently put into practice. As a result, they did not need a "pattern" associated with a specific physical place. What is more, it should be remembered that representatives of each province met every year at General Chapters in various parts of Christianitas. What they needed was unanimitas, which was manifested in the search for uniformitas.

The Church in the twentieth century, especially after the proclamation of liturgical renewal by the Second Vatican Council, faced similar problems as the Preachers at the beginning of their existence. I dare say that the process, which for the Order of the Preachers ended with the unification of the liturgy, but also with the calming of tempers, continues on in the contemporary Church. I do not know if "a reform of the reform" is the most appropriate solution, but it seems that in a spirit similar to that of the Preachers of the thirteenth century, Joseph Ratzinger is inclined to think so, asking for the right view in our approach to the liturgy, one that restores the perspective of "a precious pearl": 
[...] We need a new liturgical awareness, so that this constructive spirit will disappear. Things have gone so far that liturgical circles are making a Sunday liturgy for themselves. What is offered here is certainly a product of a few smart, efficient people who have created their own concept. [...] This peculiar or self-willed construction must disappear, the inner sense of the sacred must be awakened. When this happens, in the second stage we will be able to see where, let's say, too much has been deleted, and in this way the relationship with all of the Church's history will become clearer and alive again. I myself spoke in this way about the reform of the reform. In my opinion, first of all it would have to be a process of education, which will put an end to weeding the liturgy with our own ideas. ${ }^{44}$

It seems that the history of the Dominican liturgy can be a good example of how the liturgy should be formed and develop, that, in the end, it will become an invigorating source of the Christian life, a "precious pearl," given and assigned to the Church. As we have seen, the problem is not its susceptibility to change; indeed, there is no "liturgy for all times," fixed once and for all and unchanging. However, the problem is an attitude that sees change as an end in itself, as the only criterion for the development of the liturgy, in order to organize the liturgy only in a human way. It must be said that this is certainly not the "spirit of the liturgy" close to the first generation of Friars Preachers.

\section{BIBLIOGRAPHY}

Acta Capitulorum Generalium Ordinis Praedicatorum, edited by Franz Andreas Frühwirth, Benedictus Maria Reichert, vol. I: Ab anno 1220 usque ad annum 1303. Romae: Ex typographia polyglotta S.C. de propaganda fide, 1898.

Acta Capitulorum Provincialium Ordinis Fratrum Praedicatorum. Première province de Provence, Province Romaine, Province d'Espagne. 1239-1302, edited by Célestin Douais. Toulouse: Imprimerie et Librairie É. Privat, 1894.

Acta Capitulorum Provincialium Provinciae Romanae (1243-1344), edited by Thomas Käppeli, Antoine Dondaine. Romae: Istituto storico domenicano di S. Sabina, 1941.

B. Humberti de Romanis quinti Praedicatorum Magistri Generalis opera de vita regulari, edited by Joachim Joseph Berthier, vol. II. Torino: Marietti, 1956.

Bedouelle, Guy. Dominik czyli taska Stowa [Dominic Means Graceful Word]. Translated by Janina Fenrychowa. Poznań: W drodze, 2011.

\footnotetext{
${ }^{44}$ Bóg $i$ świat. Z kardynatem Josephem Ratzingerem rozmawia Peter Seewald, transl. Grzegorz Sowinski (Kraków: Wydawnictwo „Znak”, 2005), 382-383.
} 
Bóg i świat. Z kardynatem Josephem Ratzingerem rozmawia Peter Seewald [God and the World. A Conversation with Peter Seewald]. Translated by Grzegorz Sowinski. Kraków: Wydawnictwo „Znak”, 2005.

Bullarium Ordinis Fratrum Pradicatorum. Sub auspiciis SS. D.N.D. Benedicti XIII, pontificis maximi, ejusdem Ordinis, edited by Thomás Ripoll, Antonin Brémond, vol. I. Romae: Ex Typographia Hieronymi Mainardi 1729-1740.

Dokumenty Soborów Powszechnych. Tekst grecki, taciński, polski, vol. II: (869-1312) Konstantynopol IV, Lateran I, Lateran II, Lateran III, Lateran IV, Lyon I, Lyon II, Vienne [Documents of the General Councils. Greek, Latin, Polish, vol. II: (869-1312) Constantinople IV, Lateran I, Lateran II, Lateran III, Lateran IV, Lyon I, Lyon II, Vienne], edited by Arkadiusz Baron, Henryk Pietras. Kraków: Wydawnictwo WAM-Księża Jezuici, 2007.

Folsom, Cassian. "I libri liturgici romani." In Introduzione alla liturgia, edited by Anscar J. Chupungco, vol. I, 263-289. Casale Monferrato: Piemme, 1999.

Hinnebusch, William A. The Dominicans. A Short History. New York: Alba House 1975.

Humberti de Romanis Legendae sancti Dominici. Necnon materia praedicabilis pro festis sancti Dominici et testimonia minora de eodem, adiectis miraculis rotomagensibus sancti Dominici et Gregorii IX bulla canonizationis eiusdem, Institutum Historicum Fratrum Praedicatorum, edited by Simon Tugwell. Romae: Institutum historicum Ordinis fratrum praedicatorum, 2008.

JoRDAN Z SAKSONII. Ksiązeczka o początkach Zakonu Kaznodziejów [Jordan of Saxony: A Book about the Beginnings of the Order of Preachers]. Translated by Mirosław Wylęgała. Warsaw: Oficyna Wydawniczo-Poligraficzna „Adam,” 2008.

JURCZAK, Dominik. “Ut studium non impediatur. La relazione tra la preghiera e la „missione” nella prima generazione dei Frati Predicatori." In 'Carminalaudis'. Rispostanel tempo all' eterno. La liturgia delle Ore tra storia, teologia e celebrazione. Atti del X Congresso Internazionale di Liturgia Roma, Pontifico Istituto Liturgico, 6-8 maggio 2015, edited by Eduardo Lopez Tello García, Stefano Parenti, Marcus Tymister, 493-500. Canterano: Arcane editrice, 2016.

JuRCZAK, Dominik. "Il concetto di concelebrazione nel XIII secolo. Lettura liturgica di papa Innocenzo III e di Tommaso d'Aquino.” Ecclesia Orans no. 32 (2015): 387-429.

Koudelka, Vladimir J. "Notes sur le Cartulaire se S. Dominique.” Archivum Fratrum Praedicatorum no. 28 (1958): 95-100.

Monumenta et antiquitates veteris disciplinae Ordinis Praedicatorum ab anno 1216 ad 1348 praesertim in Romana provincia praefectorumque qui eandem rexerunt biographica chronotaxis ex synchronis documentis, ineditis codicibus, aequalibusque auctoribus collectae, illustratae, ac digestae, edited by Pius-Thomas Masetti, vol. II. Romae: Typographia Rev. Cam. Apostolicae, 1864.

SCHEEBEn, Heribert Christian. Monumenta Historica Sancti Patris Nostri Dominici, vol. II. Romae: Institutum Historicum Fratrum Praedicatorum, 1935.

The Historia Occidentalis of Jacques de Vitry. A Critical Edition, edited by John Frederick Hinnebusch. Fribourg: The University Press, 1972.

Thomas Antoninus Hendrik. De oudste constituties van de Dominicanen. Voorgeschiedenis, tekst, bronnen, ontstaan en ontwikkeling (1215-1237). Leuven: Bureel van de R.H.E., 1965.

Tugwell, Simon. "Introduction." In Humberti de Romanis Legendae sancti Dominici. Necnon material praedicabilis pro festis sancti Dominici et testimonia minora de eodem, adiectis 
miraculis rotomagensibus sancti Dominici et Gregorii IX bulla canonizationis eiusdem, edited by Simon Tugwell. Romae: Institutum Historicum Fratrum Praedicatorum, 2008.

VAN DiJK, Joseph Peter. “The Authentic Missal of the Papal Chapel.” Scriptorium no. 14 (1960): 257-314.

Translated by Jan Kobytecki

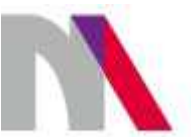

The preparation of the English version of Roczniki Teologiczne (Annals of Theology) and its publication in electronic databases was financed under contract no. 836/P-DUN/2018 from the resources of the Minister of Science and Higher Education for the popularization of science. 